\title{
Foucaultcu Bir İktidar Analizi: Türkiye'de Hapishanelerde İletişimsel Süreçler
}

Mehtap Özsoy

doktora öğrencisi, gazi üniversitesi, radyo televizyon ve sinema bölümü mehtapzsy@gmail.com

\section{Abstract \\ A Foucauldian analysis of power: Communicational processes in Turkish prisons}

This study aims to examine the communicational aspects of the practices developed by the prisoners within the prison through Foucault's analysis of power. Prisoners interviewed within this context were selected among those who had been imprisoned during the period of 1979-2002. The theoretical framework deals with power relations, Foucauldian resistance and freedom, space and prisons as a field of political conflict. The interviews were structured to examine the daily life, and creative communication techniques. Communicational processes of the prisoners are considered as a form of resistance. In this respect, the study discusses the power analysis of Foucault in a theoretical perspective while presenting a micro-scale research on the area of the exercise of power, which is an under-researched area in the literature. In this way, the power mechanism has been examined from the viewpoint of resistance dynamics.

keywords: Foucault, power, freedom, prison

\footnotetext{
* Bu çalışma 2015'te Gazi Üniversitesi İletişim Fakültesi'nde kabul edilen yüksek lisans tez çalışmamdan makaleye dönüştürülmüştür.

Bu makaleye referans vermek için: Özsoy, M., (2018). Foucaultcu Bir Iktidar Analizi: Türkiye'de Hapishanelerde İletişimsel Süreçler. Galatasaray Üniversitesi Illeti-ş-im Dergisi, 28, 257-277. DOI: 10.16878/gsuilet.436055
} 


\section{Résumé}

\section{Une analyse foucaldienne du pouvoir : les processus communica- tionnels dans les prisons en Turquie}

Cette étude vise à examiner, à partir de lıanalyse de pouvoir de Foucault, les pratiques développées par les prisonniers et l'aspect communicationnelle de ces pratiques. Les prisonniers interrogés ont été sélectionnés parmi ceux qui ont été emprisonnés dans la période de 1979-2002. Le cadre théorique traite les relations de pouvoir, les thèmes de la résistance et de la liberté foucaldiennes, l'espace et les prisons comme un champ de conflit politique. Les entretiens ont été structurés de manière à examiner la vie quotidienne, les techniques de communication créatives. Les processus de la communication ont été abordés comme une forme de résistance. Dans ce travail, en reprenant l'analyse du pouvoir de Foucault et on propose une recherche à micro-échelle dans le domaine de l'application du pouvoir. De cette façon, le fonctionnement du pouvoir est examiné du point de vue des dynamiques de la résistance.

mots-clés: Foucault, pouvoir, libérté, prison

\section{Öz}

Bu çalışma, Foucault'nun iktidar analizinden hareketle mahpusların hapishane mekânında ne tür pratikler geliştirdiklerini ve bu pratiklerin iletişimsel boyutunu incelemeyi hedeflemektedir. Çalışmada görüşülen mahpuslar 19792002 arasındaki süreci yaşayan kişilerdir. Teorik çerçevede iktidar ilişkileri, Foucault'da direniş ve özgürlük temaları, politik bir çekişme alanı olarak mekân ve hapishaneler ele alınırken, görüşmelerle hapishanelerdeki gündelik hayat, yaratıcı iletişim teknikleri sorgulanmış ve iletişimsel süreçler birer direniş biçimi olarak ele alınmıştır. Çalışma, bu anlamıyla Foucault'nun iktidar analizlerini teorik bir bakışla ele alırken literatürde eksik olduğu gözlemlenen iktidarın uygulama alanına dair mikro ölçekte bir araştırma sunmuştur. Böylelikle iktidarın işleyişi direniş dinamikleri penceresinden değerlendirilmiştir.

anahtar kelimeler: Foucault, iktidar, özgürlük, hapishane 


\section{Giriş}

İtidarı, süreğen, çatışmalı ve dinamik bir işleyişle ele alan Foucault'ya göre iktidar çatışmalı bir ilişkiyle işler. Foucault iktidarı sadece doğrusal bir şekilde yukarıdan yani devlet, bürokrasi ya da belli kişi/gruplar tarafından dayatılan bir olgu olarak değil toplumsal düzlemde işleyen karmaşık, çatışmalı ve stratejik ilişkiler ağı olarak değerlendirir. İtidar Foucault'ya göre yalnızca teorik bir sorun değil deneyimlerimizin bir parçasıdır (Foucault, 20111, s.59) Foucault bir iktidar tanımı yapmaktan, iktidarı betimlemekten çok, onun nasıl işlediği ve toplumsal ağlar içinde nasıl dolaşıma girdiği üzerinde durur. Modern devlet biçimini bilgi-iktidar bağlamı çerçevesinde değerlendiren Foucault'ya göre iktidar tıp, psikoloji gibi alanlar üzerinden söylemsel pratiklerle yaşamsal bilgiler üretip bireyi nesneleşme süreçlerine tabi tutarken, hapishane, akıl hastanesi, okul gibi kurumlar yoluyla bu söylemsel pratiklerin uygulandığı alanlar üretir. Bu üretim ve dönüşüm süreklilik arz eder.

Foucault, bir iktidar tanımından çok, onun nasıl işlediğini ve içeriğini ortaya koymak gerektiğini düşünür. Foucault iktidar ilişkilerinin içeriğini anlamak için teori ve pratik arasında daha fazla ilişkiyi barındıran bir yol önermektedir. Bu doğrultuda direniş biçimleri ve bu biçimleri ayrıştırmaya yönelik girişimlerle bir iktidar analizi yapılabilir ve iktidar ilişkilerinin içeriği değerlendirilebilir (Foucault, 20112, s. 61). Foucault, iktidar analizinde her dönemin epistemolojisine uygun olarak üretilen iktidar tekniklerinin altını çizer. Bu doğrultuda özellikle modern devletin bireyleri nesneleştirmek ve onları kendine tabi kılabilmek için ürettiği teknikler ve üretilen yeni öznellik alanlarına eğilen Foucault için özne tanımı önemlidir. Çünkü iktidar kategorize edilen özneler üzerinden de işler. Özne sadece iktidara boyun eğen, deli-akıllı, suçlu-suçsuz gibi ikiliklerle bölünen ve yeniden üretilen pasif bireyleri değil, aynı zamanda "kendilik kaygısı taşıyan özgür özneler" olan bireyleri de kapsar. İktidar bu anlamıyla özgür öznelerin iktidara karşı geliştirdiği taktik, strateji, reddediş doğrultusunda üretilen tekniklerin ve özgür öznenin yeniden nesneleştirilebilmesi, uysallaştırılması için iktidar tarafından üretilen yeni teknolojilerin üretildiği pratikleri kapsar.

Foucault'nun bu analizleri, özellikle özgür özne ve iktidar tekniklerinin özneler üzerindeki işleyişi, özgür öznenin iktidara karşı ürettiği pratikler çalışmadaki problematiğin temelidir. Bu bağlamda çalışmada iktidar pratiklerinin üretildiği Türkiye'deki hapishanelerde iktidar ilişkileri, iletişimsel süreçler ve iktidara karşı geliştirilen direniş biçimleri ele alınmıştır. Çalışma, Foucault'nun iktidar analizlerini temel alarak Türkiye'deki hapishanelerde birincisi 1979-1992; ikincisi 1983-1984; üçüncüsü 1992-2002; dördüncüsü 1998-2001 yılları arasındaki süreci yaşayan kişilerin iktidara direniş doğrultusunda geliştirdikleri pratikleri

1 Kitabın ilk orijinal basımı 1994'tür.

2 Kitabın Fransızca ilk orijinal baskısı 1994'tür. 
kapsamaktadır. Görüşmecilerden biri kadın diğerleri erkektir. ${ }^{3}$ Görüşmeler 2013'te ses kaydı alınarak yapıımıştır. Çalışmada nitel araştırma yöntemlerinden biri olan derinlemesine görüşme tekniği kullanılmıştır. Böylelikle görüşmecilerin deneyimleriyle hapishanelerin, mekânsal, teknik ve içeriksel dönüşümü içeriden bir bakışla ele alınmıştır. Görüşmelerde hapishane mekânındaki iletişim yolları birer direniş biçimi olarak irdelenmiş ve bu iletişimsel süreçler üzerinden gerçekleşen iktidar tekniklerinin hapishaneler üzerinden dönüşümü ele alınmıştır. Çalışmadaki görüşmeciler sistematik bir seçime tabi tutulmamıştır, sadece görüşmeyi kabul eden kişiler ele alınmaktadır. Bu anlamda çalışmanın bütünü temsil etme gibi bir iddiası yoktur. Bu doğrultuda çalışma literatürde yeterince ele alınmadığı düşünülen bir alan araştırmasının "keşif" aşaması olarak veya bir giriş başlangıç olarak değerlendirilmelidir.

\section{Foucault'nun iktidar analizine genel bir bakış: modern devlet}

Foucault, modern devlet biçimine dair çözümlemelerini bilgi-iktidar bağlamına yerleştirir. Bilgi, modern devlet için iktidarı farklı kanallarla uygulamanın en etkili aracı olmakla kalmaz, aynı zamanda iktidarın kendisidir. Bireylerin bilgisine sahip olan iktidar, bilgiye sahip olma aşamasında, yeni bilgi nesneleri ve bu nesnelere bağlı yeni öznellikler üretir.

Bireylerin yaşamlarını yönlendiren ve onlara yeni yaşam biçimleri üreten iktidar, özellikle on sekizinci yüzyılın sonundan itibaren bilginin üretildiği tıp, psikiyatri, psikoloji gibi söylemsel pratikler ve bu söylemsel pratiklerin uygulanıp yeniden üretildiği kurumlar üzerinden bireye öznellikler atfeder. Akıl hastalığı, hastalık ya da suç gibi varlık biçimleri üzerine nesnel anlamda doğru olma, hakikat iddiası taşıyan önermeler içeren ve üreten pedagoji, patoloji, kriminoloji, psikiyatri, psikoloji gibi bilimsel araştırma alanları söylemsel pratikleri oluştururken; hastane, akıl hastanesi, hapishane, kışla, okul gibi modern tecrit kurumları da araştırma alanları için gereken ortamı sağlayan söylemsel olmayan pratikleri içerirler (Keskin, 2011, s.16). Foucault'nun bu bağlamda bilgi-iktidar ilişkisine bağlı olarak ortaya koyduğu önemli bir kavram biyo-iktidardır.

Geleneksel iktidar modellerinin, beden ve yaşamı yok etmeye ilişkin teknikleri, moderniteyle birlikte yerini beden ve yaşamı devam ettirme tekniklerine bırakır. Beden siyasal bir anatomiye dönüşür. Bu siyasal anatomide siyasal beden iktidar ve bilgi ilişkisi yoluyla tabi kılınarak bilgi nesnesi haline gelir. Böylelikle beden, iktidar ve bilgi ilişkisine silah, menzil, iletişim yolu ve destek noktası olarak hizmet eden maddi ve teknik unsurların bütünü haline gelir (Foucault, 19924, s.34).

3 Görüşmecilerin cinsiyetleri özellikle seçilmemiştir. Görüşmeciler imkânlar doğrultusunda ulaşılabilen kişilerdir.

4 Kitabın Fransızca orijinal basımı 1975'tir. 
Foucault'nun her türlü bilimin ötesine geçen ancak "söylemsel düzenlerin seviyesinde analiz edildiği zaman bilimlerin arasında belirli bir çağ için keşfedilecek olan ilişkiler bütünü" (Foucault, 20115, s.222) olarak değerlendirdiği episteme farklı çağlarda başka ilişkiler ağı için "hakikatler" üretir. Bu anlamıyla modern episteme kendi dönemi içinde yaşamın kutsalığı, disiplin, denetim gibi söylemsel pratikler etrafında hakikatler üretir.

\section{İktidar-özgürlük ilişkisi}

Toplumsal ilişkilerin her alanına sızan iktidar, direniş biçimleri ile birlikte toplumsal olanı belirler. Direniş biçimleri ise iktidar tarafından üretilen özneleşme süreçlerine karşı geliştirilen stratejileri, çekişme alanları üzerinden iktidar ile çok boyutlu bir ilişki biçiminde toplumsal durumu ortaya çıkarır.

İktidarı bir ilişkiler ağı olarak ele alan Foucault'ya göre iktidar ilişkileri kurumlar aracılığıyla rasyonelleşip merkezileşir. Bu haliyle de iktidar ilişkileri gün geçtikçe devletleşen bir forma sahiptir (Foucault, 20116, s.79) Devletleşen bu iktidar ilişkileri, potansiyel olarak kendi içinde bir mücadele stratejisini içerir. İktidar, on yedinci ve on sekizinci yüzyılla birlikte yararlılık ilkesi çerçevesinde bireylerden verimli hizmet almayı hedefler. Ancak, bireyin yararlılık ilkesi etrafında nesneleştirilmesine dayanan öznellikler aynı zamanda nesneleştirilmeye bağlı bağımlılık ilişkisini kabul etmeyip yeni direniş alanları üretir (Revel, 2005, s. 134-135). Bu yeni direniş alanlarında bağımlılık ilişkisini kabul etmeyen, kendilik kaygısı taşıyan ve iktidarın oluşturduğu bilgi alanlarının dışına çıkarak iktidara tabi olmayı kabul etmeyen "özgür özne" iktidarın yeni teknikler, teknolojiler geliştirebilmesinde iktidarı zorlayan bir kavramdır. Özgür öznenin yeniden uysallaştırılabilmesi için iktidar yeni teknikler üretir.

İktidar belirli özgürlük alanlarında tehlikeye girer; ancak bu özgürlük alanları olmaksızın bir iktidar varlığından bahsedilemez. İktidar ilişkisinin özünde yatan ve onu sürekli olarak kışkırtan harekete geçiren etken, istencin boyun eğmeyişi ve özgürlüğ̈̈n inadıdır (Foucault, 2011, s.76).

Dolayısıyla, Foucault'ya göre disiplinci toplum demek tamamen disipline olmuş toplum demek değildir. Yani her ne kadar disiplin yöntemleri hızla yayılıp gelişse de bu durum insanların tümüyle itaatkâr olduğu anlamına gelmemektedir. Bu anlamda Foucault "normalizasyon" toplumlarında kitlesel ve direnilemez bir normalizasyon olduğu iddiasını ortaya atmaz (Keskin, 2011, s. 21-22). Fakat özgürlüğü belirlemek eğiliminde olan iktidar buna rağmen özgür özneler üzerinde ve özneler özgür olduğu sürece uygulanır (Foucault, 20117, s.75). Özne kelimesi Foucault için tek bir anlam taşımaz. Özne iki farklı anlama sahiptir. Bunlardan

5 Kitabın Fransızca orijinal basımı 1969'dur.

6 Kitabın Fransızca orijinal basımı 1994'tür.

7 Kitabın Fransızca orijinal basımı 1994'tür. 
biri denetim ve bağlılık yoluyla başkasına tabi olan özne diğeri ise vicdan ve özbilgi yoluyla kendine tabi olan öznedir. Ancak Foucault, iktidarı analiz ederken, iktidarın işleyişinde, teorik olarak onun amacından ya da niyetinden çok pratikteki durumuna bakar. Bu bağlamda Foucault, bir iktidar tanımı yapmaz iktidarı bir tür ilişki olarak ele alır ve bu ilişkilerde farkı iktidar biçimlerine karşı geliştirilen direniş biçimlerini çözümlemeyi önerir ((Foucault, 20118, s.61-63).

Bu noktada iktidarı genel, makro ölçeklerle değerlendirip, onu tanımlamaya çalışmak yerine Foucault'nun önerdiği yoldan giderek mikro boyutlardaki iktidar ilişkilerine bakmak bu ilişkileri çözümlemek, sorgulamak ve değerlendirmek iktidar ilişkilerinin analizini yapmamızı olanaklı kılacaktır. Hapishaneler, okullar, dini kurumlar, hastaneler gibi iktidarın uygulandığı mekânları ele almak, iktidarın işleyişini, onun bireyler üzerindeki etkilerini, iktidarın dönüşümünü anlamak için önemlidir.

\section{Modern bir iktidar tekniği: hapsetme ve hapishaneler}

Foucault çalışmalarında kapatılma ve gözetleme pratikleri ile modern devlet rasyonalitesi arasındaki ilişkinin altını çizmektedir. Akıl hastanesi, hapishane gibi kurumların kapatılma mantığı içerisinde yer alan gözetleme pratiği zamanla her an denetlenen, gözetlenen, sürekli bir disipline tabi olan geniş ölçekli sürekli gözetlenen bir toplum fikri yaratmıştır. Bu fikir bağlamında yeni iktidar teknolojileri üretilmiştir. Aslında kişiyi herhangi bir yere hapsetme geleneğine birçok uygarlıkta rastlamaktayız. Ancak hapsetme pratiği modern devletten önce bir ceza olmaktan çok asıl cezanın uygulanacağı zamana kadar kişinin bir mekânda kapatılmasını içerir. Kişiyi özgürlüğünden yoksun bırakarak cezalandırma pratiği ise hapishane mekânının bugünkü anlamıyla varlık sebebidir.

Foucault 1975'te yayınlanan cezanın bir seyirlik unsur olarak bedeni hedef alan azap tekniklerinden kişinin disiplin ve sürekli gözetime tabi tutulması yoluyla yararlı ve itaatkar hale getirilmesini hedefleyen farklı ceza pratiklerini incelediği, iktidar teknikleri ve iktidar ilişkilerinin tarihini ele aldığı Hapishane'nin Doğuşu adlı kitabında on sekizinci ve on dokuzuncu yüzyıldaki cezalandırma pratiğine ve iktidar işleyişine dair şöyle söyler:

XVIII. yüzyıl ile XIX. yüzyılların dönemecinde kapalı tutulmaya dair bir cezalandırma sistemine geçildiği doğrudur ve bu yeni de değildir. Fakat söz konusu olan cezalandırma sisteminin başka yerlerde daha önceden geliştirilmiş olan baskı altına mekanizmalarına açılmasıdır. [...] Hapishane biraz daha sıkı bir kışla, hoşgörüsüz bir okul, iç karartıcı bir atelyedir, ama limitte bunlardan niteliksel olarak hiçbir farkı yoktur. Bu çifte temel-bir yandan hukuki-ekonomik, diğer yandan teknik-disiplinsel- hapishaneyi bütün cezaların en dolaysız ve en uygunu olarak ortaya çıkarmıştır. Ve ona sağlamlığını hemen sağlayan şey bu çifte işleyişi olmuştur.

8 Kitabın Fransızca orijinal basımı 1994'tür. 
Ancak on sekizinci yüzyıldan önce bireyler üzerinde uygulanan ceza pratikleri ya bedene uygulanan azap yöntemleri ya da belirli bir süreliğine bir bedel karşılığında bedel ödeninceye kadar bireyin kapatılmasını kapsamaktaydı. Bu anlamda Orta Çağ'da kurumsal anlamda hapishaneler yoktur. Insanlar hücrelere yargılanıncaya, fidye ödeyinceye ya da infaz edilinceye kadar kapatılmaktadırlar. Aynı zamanda Orta Çağ'da, bugünkü anlamda hapsetme başlı başına bir ceza pratiği olmadığı gibi kitlesel anlamda da kapatılmalar söz konusu değildir. Ancak on yedinci yüzyılla birlikte Paris'te tarihsel olarak bir dönüm noktası yaşanır. Altı binden fazla insan bu dönemde -ki bunlar yersiz-yurtsuz, evsiz ve işsiz insanlardırsürekli olarak bir gözetime tabi olmuşlar ve kitlesel bir şekilde Hospital General adında bir kuruma kapatılmışlardır (Foucault, $2011^{9}$, s. 105). Zamanla kurumsallaşan ve çoğalan bu tarz mekânlar bireylerin kategorize edilerek sürekli bir gözleme ve deneye tabi tutulabilmeleri için bulunmaz bir imkân sağlamıştır.

Kutsal yaşam hakkı bağlamında on sekizinci yüzyılın sonu ile on dokuzuncu yüzyılın başında ceza fiziksel yapı üzerinde acı çektirme, örneğin bedenin parçalanması organların koparılması şeklinde seyirlik bir oyun olmaktan çıkarak kişinin dışarıdaki dünyaya uygun hale getirilmesi fikrine dönüşmüştür. Kişinin cezalandırılması karanlık bir şenlik halinden yavaş yavaş sıyrılmaya başlamış ve beden ceza ile yıldırmanın ana hedefi olmaktan çıkmıştır. Cezanın törensel yanı karanlığa bürünerek cezayı bir sahne olmaktan çıkarmıştır (Foucault, 1992 ${ }^{10}$, s. 9).

1604 'te I.James yönetiminde daha önce başıboş koyunlara uygulanan damgalama yöntemi artık insanlara da uygulanmaya başlanmıştır. Bu yöntemin amacı esasında sürekli hareket halinde olan suçlu insanların "yerel gözetim yoluyla denetim" ağları içerisinde yer almalarını sağlayarak onları görünür kılmaktır. Damgalama sayesinde tehlikeli insanlar ayırt edilip yakın gözetim altına alınarak denetimin gerçekleştirilmesi amaçlanmıştır. 1604 tarihli yasa damgalamakla ilgili şunu söylemektedir: "deriye ve ete o şekilde dağlanıp, işlenmeli ki, 'R' harfi görülsün ve böyle bir alçağın (rogue) üzerinde yaşamı boyunca sürekli bir işaret olarak kalsın" (Bauman11, 2012, s.57). On yedinci yüzyılda bu yasa ile ortaya iki farklı kategori çıkmaktadır. Sürekli izlenme ve fark edilme kaygısıyla yaşayan suçluların oluşturduğu bir kategori olarak izlenenler ve onları her an denetlemeye hazır olan çoğunluğun oluşturduğu izleyenler kategorisi.

Ancak bir sonraki yüzyılda yani 1785 'te çok daha teknik ve ekonomik bir gözetim ve denetim projesi üretilir. Bu proje Jeremy Bentham'ın, bir hapishane projesi olan "panoptikon" tasarımıyla ortaya çıkmıştır. Bu projenin asıl önemi, disiplinin yalnızca hapishane akıl hastanesi gibi kapatılma kurumlarıyla değil, topluma dağılmış olan denetim odaklarıyla da yaygınlaşabileceğini gösterebilmiş olmasıdır. Panoptikon projesinin mimari biçimi, hapishanedeki mahkûmların

9 Kitabın Fransızca orijinal basımı 1994'tür.

10 Kitabın Fransızca orijinal basımı 1975'tir.

11 Kitabın İngilizce orijinal basımı 1987'dir. 
merkezde bulunan bir bekçi tarafından sürekli olarak izlenebilmesini olanaklı kılmaktadır. Çevrede halka halinde bir bina, merkezde bir kule; bu kulenin halkanın iç cephesine bakan geniş pencereleri vardır; çevre bina hücrelere bölünmüştür. Bunlardan her biri binanın tüm kalınlığını katetmektedir. Bunların biri içeri bakan ve kuleninkilere karşı gelen, diğeri de dışarı bakan ve ışığın hücreye girmesine olanak veren iki pencereden oluşmaktadır. Böylelikle mahkûmlar hiçbir zaman göremedikleri bekçi tarafından her an gözetlendikleri bilgisine sahip oldukları için kendi kendilerini denetleme yoluna gireceklerdir (Foucault, 199212, s. 251).

Böylelikle artık soruşturma yoktur, gözetleme inceleme vardır. Bireyler üzerinde bir iktidar uygulayan ve iktidar uyguladıkça gözetledikleri üzerinde bilgi edinme imkânına sahip biri örneğin müdür, doktor, psikiyatr ya da hapishane müdürü tarafından sürekli bir gözetim söz konusudur. Yani ortaya yeni bir bilgi çıkmıştır. Bu yeni bilgi: "bir şeyin olup olmadığını belirlemekten çok bireyin gerektiği gibi davranıp davranmadığını, kurala uygun olup olmadığını belirleyen bilgi"dir (Foucault, 2011'13, s.225). Proje Foucault'ya göre sadece bir hapishane projesi değil aynı zamanda yeni bir iktidar tekniği olarak denetim ve gözetim toplumu olan panoptik tarzda bir toplum inşasını da mümkün kılmıştır.

\section{Hapishanelerde bir direniş pratiği olarak iletişim}

Bilgi öznesinin bir tarihi vardır, öznenin nesneyle ilişkisinin veya daha açıkçası hakikatin kendisinin bir tarihi vardır ${ }^{14}$

\section{Mekân-iletişim ve iktidar}

Hapishaneler her ne kadar bir kapatılma kurumu olsalar da iktidar ilişkilerinin yaşandığı, mahkûmların kendi yaşamsal pratiklerini ürettikleri çatışmalı mekânlardır. Bu pratikler nelerdir, hapishanelerdeki gündelik hayat nasıl akmaktadır ve hapishanelerin bugün geldiği mekânsal dönüşüme kadar geçen süreç bir taraftan iktidara tabi kılınmak için bilginin nesnesi haline getirilmek istenen ancak diğer taraftan kendi öznelliklerini yaratma kavgası veren mahpusların yaşamları üzerinde nasıl etki etmiştir? Bütün bu sorular elbette çoğaltılabilir. Ancak her an denetim ve gözetime tabi tutulmak istenen mahkûmların en temel insani deneyim olan iletişimsel süreçleri nasıl gerçekleştirdikleri ve iletişim üzerindeki çekişmenin nasıl yaşandığı sorusu çalışmamızın bu bölümündeki odak noktasıdır. Çünkü iletişim yalnızca toplumsal aktörlerin içinde bulunduğu anlam sistemlerini değil, aynı zamanda egemenlik ilişkilerini de üretir. Bu anlamıyla da güç/iktidar ve iktidara bağlı görüşlerin çatışmasıdır. Bu niteliğiyle iletişim, iktidar meseleleri ve güç uygulayımı ile içsel bir bağa sahiptir (Dursun, 2013, s.25). Mekânı bir

12 Kitabın Fransızca orijinal basımı 1975'tir.

13 Kitabın Fransızca orijinal basımı 1994'tür.

14 Foucault'nun 1973'te Yüksek Katolik Üniversitesi'nde verdiği konferanstan alıntıdır. Bknz. Büyük Kapatılma, Ayrıntı:2011. 
iktidar pratiğiyle birlikte ele almak, aynı zamanda mekânın üretim süreçleri ve varlığı üzerinden kimlik oluşumları, ideoloji, aidiyet ve direniş gibi kavramları da okumamıza olanak sağlamaktadır. Harvey'e göre mekân kendi başına mutlak, göreli ya da ilişkisel değil duruma göre bunlardan bir ya da birkaçı olabilmektedir. Mekânın uygun kavramlaştıııması sorunu insan pratiklerinin mekânın karşısındaki durumuna göre sonuçlanmaktadır. Mekâna ilişkin tüm sorgulamalar insan pratiklerinde yatmaktadır. Bu nedenle, mekân nedir sorusunu sormak yerine değişik insan pratiklerinin değişik mekân kavramlaştırmaları içindeki yeri sorgulanmalıdır. Örneğin, mülkiyet ilişkisi tekelci denetimin içinde işleyebileceği mutlak mekânlar yaratmaktadır (Harvey, 201315, s.19). Bu bağlamda gerek toplu konutlar gerek kamusal mekânlar gerekse hapishane ve okul gibi kurumların mekânsal inşası ve işleyişi insan pratiklerinden, toplumsal durumlardan, dönüşümlerden ve iktisadi süreçlerden bağımsız değildir. O halde mekânı anlamak toplumsal dönüşümü anlamakla da mümkündür. Bu noktada, modern kurumların fiziksel inşası modernizmin düşünsel zemininden ve onun bu zeminle dönüştürdüğ̈ beden, birey ve toplum inşasından bağımsız değildir. Bunun yanı sıra mekânsal dönüşümler insanın gündelik hayat pratiklerinden ve varoluşundan bağımsız değildir. Mekân bu varoluşsal düzlemiyle bireyin bedensel, duygusal ve düşünsel süreçlerini hem şekillendiren hem de birey tarafından yeniden üretilen bir özelliğe sahiptir.

Mekânı antropolojik boyutuyla ele almak; "yer" ile "mekân" arasındaki ayrımı ortaya koymak demektir. Mekânın yer olmaktan çıkabilmesi için iletişim olgusunu barındırması gerekmektedir. Çünkü mekân ancak bir insani deneyim olan iletişim ile ilişkisi halinde mekân olur (Öztürk, 2012, s.14). Hapishaneler de kapatılma mekânları olarak iletişimsel deneyimlerin yaşandığı yerlerdir. Ancak mahkûmların iletişimsel süreçleri üzerinde sürekli bir kontrol vardır ve iletişim deneyimi üzerinde sürekli bir çekişme söz konusudur.

Mekânın kendisi, iletişimsel bir deneyim olarak bir anlam inşasıdır. Ancak anlamın inşası çelişkisiz olup biten bir süreç değil hangi yorumun hâkim hale geleceği ile ilgili mücadeleyi de kapsar (Dursun, 2013, s.25).

Bu noktada iktidarın kendi belirlediği ve intiyaç duyduğu koşullara göre iktidar tarafından farklı dönemlerde farklı intiyaçlar doğrultusunda dönüştürülen hapishanelerde, iletişimsel süreçleri kontrol eden teknikler ile insani bir deneyim olan iletişim pratiğinin belirlenen asgari düzeyleri aşan bir şekilde yaşanması güç/ iktidar çatışmasını doğurmaktadır.

\section{Hapishanelerde bir direniş biçimi olarak iletişim örnekleri}

Çalışmanın bu bölümünde Foucault'nun iktidar analizleri doğrultusunda 2013 yılında dört siyasi mahpusla yapılan derinlemesine görüşmeler değerlen-

15 Kitabın İngilizce orijinal basımı 1973'tür. 
dirilecektir. Görüşmecilerden ilki, 1979- 1990; ikincisi 1983-1984; üçüncüsü 1992- 2002; dördüncüsü 1998-2001 yıllarında hapishane deneyimlerini yaşayan kişilerdir16. Görüșülen dört kişinin ortak noktası siyasi mahpuslar olmalarıdır. Bu görüşmelerdeki amaç, bir taraftan özgürlük/direniş alanı yaratımında geliştirilen anlam yaratımı, haber alışverişi olarak ele alınan yaratıcı iletişimsel süreçleri, gündelik hayatın akışını değerlendirmek, diğer taraftan toplumsal tarihin bir envanteri olan hapishanelere ve hapishanelerin dönüşümüne aşağıdakilerin gözüyle bakabilmektir.

Yapılan görüşmeler ışığında elde edilen veriler üç bölümde değerlendirilmiştir. Bunlar, gündelik hayata dair eğlenmek, hoş vakit geçirmek için mahpuslar tarafından üretilen yaratıcı deneyimler, disiplin-denetime karşı geliştirilen deneyimler ve mahpusların birbirleriyle iletişim kurmak için geliştirdikleri yaratıcı haberleşme yöntemleridir.

\section{Hapishanede gündelik hayat}

Mahpusların gündelik hayatlarını geçirdikleri koğuşlar, insani birtakım meşgalelerin üretildiği pratikleri kapsayan yerlerdir. Örneğin, hapishanelerde pasta yapmak, satranç oynamak, çeşitli yarışmalar düzenlemek gibi günlük rutinin dışına çıkmak için birtakım faaliyetler gerçekleştirilmektedir. Gündelik hayatın örgütlenmesi mahpuslar için önemli bir yerde durmaktadır. Çünkü hapishane yönetimi/iktidarı ve mahpuslar arasındaki sürekli bir çekişme alanıdır gündelik hayat. Bir eğlence biçimi olarak tüm imkânsızlıklara rağmen üretilen satranç araçları da gündelik hayatın mahpuslar cephesinden örgütlenişidir:

Ekmek içi ve gazete kağıtlarından satranç taşları yapılıyordu. Satranç tahtası ise koğuşun zeminine çizilen bir plan ile sağlanmış oluyordu. Her koğuştan bir kişi seçiliyor, koğuş mazgallarından bir temsilci, yapılan hamleyi bağırarak söylemekteydi. Bu oyunlar bazen aylarca sürerdi, hatta öyle durumlar yaşanırdı ki arkadaşlar arasında oyundan kaynaklanan dargınlıklar bile olurdu (II. Görüşmeci/1983-1984)

Oyunların arasında birinci görüşmeci olan mahpusun kültürel bir faaliyet olarak değerlendirdiği bit yarışı da vardır:

Bit yarıştırma işi yaptık. Bit yarıştırma işi bize göre kültürel bir faaliyetti çünkü Anadolu'daki hapishanelerde bitlenme olayı meşhurdur. 80'den önce koğuşlarda çok bit vardı. Ilaçlama yapılmıyordu bitler o kadar çoktu ki tıkır tıkır bit kırardık. O bitleri arkadaşlar getirirlerdi, kutuya koyarlardı, kutuda bitler yürürdü biz de o bitleri yarıştırır, eğlenirdik. Böylelikle kendi kendimize hem günü geçirecek hem de haşerat sorunundan kurtulacak yöntemler buluyorduk. (I.Görüşmeci/1979-1990)

16 Görüşmeciler çalışmada; şeklinde hapishaneye giriş ve çıkış tarihlerini ifade etmek üzere I. Görüşmeci (1979-2000), II. Görüşmeci (1983-1984); III. Görüşmeci (1992-2002); IV. Görüşmeci (1998-2001) şeklinde ifade edilmiştir. 
12 Eylül 1980 darbesiyle birlikte toplumsal hayatın her alanında olduğu gibi hapishanelerde gündelik pratiklerin işleyişi zorlaşır. Sıcak su, yiyecek gibi gündelik temel intiyaçlar üzerindeki baskı artar. Eğitim çalışmalarından, yasaklı kitapların tedarikine, sıcak su elde etmeye ve çiçek yetiştirmeye kadar devam eden bir inatlaşma bir mücadele alanı olarak ele alabileceğimiz koğuş yaşamı, tüm baskılara rağmen mahkûmların geliştirdiği direniş biçimlerinin de alanı olur. Çünkü, gündelik hayat sayısız özel vaka ve öngörülemez durumla birlikte isyan eder (Lefebvre17, 2013, s.73). Gündelik hayat "Sana rağmen sıcak bir şeyler içebiliyorum"un çekişmesine döner:

Günün belirli saatlerinde kısıtlı olarak idare tarafından sağlanan sıcak su bizim gündelik ihtiyaçlarını karşılayamıyordu. Çay içmek bizim için kısıtı şartların içinde önemli bir yerde duruyordu. Bizden alınan her şeyin yerini yine biz doldurmaya çalışıyorduk. Bu bir inatlaşmaydı: "Sana rağmen sıcak bir şeyler içeceğim"in mücadelesiydi. Ampul sıcak su sağlamadaki araçlarımızdan biriydi. Ampulün alt tarafı kırılıp üstteki duy kısmı tekrar yerine takılıyor. Ampulün elektrik ileten tellerine sigara paketinin alüminyum kısmı bağlanıyor. Su dolu bardağın içine sarkıtılan alüminyum sayesinde su ısınmaya başlıyor. Böylece sıcak suyumuzu dilediğimiz şekilde kullanabiliyorduk. Bunun yanında özel günlerimiz de oluyordu. Koğuş içinde bu günleri kutlamak bizim de hakkımızdı. laşe sırasında gelen kompostoları saklayarak şarap bile yapıyorduk. (II. Görüşmeci/1983-1984)

Koğuş sistemi içinde mahpuslar toplumdan yalıtılmışlığın önüne geçmek için birlikte etkinlikler yapmaya özen gösterdiklerini ifade etmişlerdir. Yemek yemekten voleybol oynamaya kadar birçok gündelik pratik kendilerinin belirlediği plana uygun şekilde yapılmaktadır:

Onların amaçladıkları tersi yönde hapishaneyi nasıl kullanabiliriz sorusu bizim için önemliydi. Toplumdan koparmak için bizi hapsettikleri yerde kendimizi birbirimizi geliştirmek, yaşam enerjimizi sağlamak için birlikte etkinlikler yapmak zorundaydık. Sonuçta hapsetme bizi yalnızlaştırma politikasıdır. Buna karşı bedensel ve düşünsel olarak kendimizi diri tutmak zorundaydık. Bir günü özetlersem; sabah 6-7 gibi kalkıp bir saat kadar spor yapıp ardından duş alıyorduk. Sonrasında toplu bir şekilde kahvaltı hazırlıyorduk. Öğleden sonra kitap okuyarak eğitim çalışması yapıp ardından akşamüstü voleybol türü maçlar yaparak ya da toplu volta atıp birbirimizin derdini dinleyerek günümüzü tamamlıyorduk (III. Görüşmeci/1992-2002)

İletişimsel pratiklerin hemen hemen yok edilmeye çalışıldığı F Tiplerinde mahpuslar birbirleriyle sosyal anlamda iletişim kurabilmenin yollarını inşa etmeye çalışırlar. Bu duruma karşı hem onlara dayatılan "yalnızlaştırarak ıslah etme" pratiğine hem de onları steril, temiz fakat sessizliğin hüküm sürdügü bir hapsetme hayatına mecbur bırakan iktidara karşı farklı bir direniş biçimi geliştirirler:

Kaldığımız F Tipi hapishanelerde diğer mahkûmlarla hem sosyalleşebilmek hem de birbirimize destek olmak için bir radyo yapmıştık. Radyo bizdik. Aslında buna bir radyo programı demek daha doğru olur. Hücredeki pencerelere çıkarak

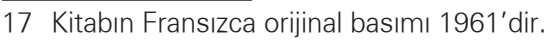


her akşam 21.00'de şarkılar söyleyip, şiirler ve hikâyeler okuyorduk. Diğer hücredekiler de isteklerde bulunuyordu. Birbirimize bağırarak duyurduğumuz sesin adına da radyo demiştik. (IV.Görüşmeci/1998-2001)

\section{Disiplin-Denetime Karşı Yaratıcı Geliştirilen Yaratıcı Deneyimler}

Hapishaneler disiplin, denetim ve gözetim tekniklerinin sürekli olarak geliştirildiği ve uygulandığı mekânlardır. Hapishanelerde kullanılan disiplin ve gözetim teknikleri ülkedeki ve dünyadaki ekonomik, iktisadi ve toplumsal dönüşümlerle beraber değişmektedir. Örneğin, 1970'lerde hapishanelerde disiplin, denetim ve gözetim sağlamak için gardiyan, askeri görevliler ya da bekçiler kullanılırken 2000'lere doğru kamera kullanımı yaygınlaşmıştır.

Bedensel ve zihinsel süreçler üzerinde kurulan denetim ve disiplin tekniklerinden biri ameli (pratik) ve nazari (teorik) eğitimlerdir. Ameli eğitimlerde mahpuslar bedensel pratikler yaparken (koşu gibi) nazari eğitimlerde koğuş mazgallarından yüksek sesle askerlerin gözetiminde kitaplar okumaktadırlar. Kitaplar genellikle kahramanlık, vatan sevgisi, savaş ve askerlik gibi konuları içermektedir. İki eğitim türü de mahpuslar tarafından haberleşme biçimine dönüştürülmektedir:

Ömer Seyfettin nazari eğitim sırasında sıkça okutulan yazarlardan biriydi. Biz bu eğitimlerde hikâye kahramanlarının isimlerini değiştirirdik. Bunu da diğer arkadaşlarımıza bilgi vermek için yapardık. Diyelim ki Ali adında bir arkadaşımız emniyete götürüldü. Okuduğumuz hikâyenin karakteri de Pehlivan Mehmet olsun. Biz bunu şu şekilde değiştirirdik: "Pehlivan Ali düşman kuvvetleri tarafından zorla götürüldü" Bu yöntemi bazen de sadece yan koğuş ile sohbet etmek için kullanırdık. Ameli eğitimlerde ise, mola verilirdi. Bu molalarda, havalandırma duvarlarında oluşan çatlaklara önceden hazılladı̆ı̆ımı notlar konulurdu. Her siyasi yapının duvarda not bırakacağı yeri bilirdik. Bu boşluklar bizim için bir nevi posta kutusuydu. (I. Görüşmeci/1979-1990)

Mahpuslar idarenin belirlediği disiplin ve denetime uymadığında çeşitli cezalara maruz kalırlar. Bu cezalardan biri hücre cezasıdır. Hücrelerde, gözetim ve disiplin en üst boyuttadır. Bu süreçte yüksek sesle konuşmaktan okunan gazetelere kadar hemen her şey sıkı kontrol altına alınır. Hücre cezasında yan hücredeki arkadaşlarının durumları hakkında bilgi edinmek de kolay değildir. Bu süreçte mahpuslar aynı zamanda ülke gündeminden de uzak kalmaktadırlar. Bilgi üzerindeki bu kontrol hem onların tek bir merkezden bilgi almalarını hem de dış dünyadan tamamen soyutlanmalarına neden olmaktadır:

Hücrede her şeyimiz sıkı bir şekilde denetleniyordu. Hücrede kaldığımız sürede hem diğer arkadaşlarımızı hem de yan hücredeki arkadaşlarımızı merak ediyorduk. Ülkede neler olup bittiğini öğrenmek de çok zordu. Her hücreye farklı gazeteler veriliyordu bazen de gazete hiç getirilmiyordu. Hücrelerin önünde iki asker sürekli nöbet tutardı. Farklı yönlere doğru volta atan askerlerin sırt sırta verdiği kör nokta bizim için çok önemliydi. Çünkü yalnızca bu anda iki görevli de çok kısa süreliğine de olsa bize arkasını dönmüş oluyordu. Biz tam bu anda, 
gazeteleri rulo yaparak yan hücreye atıyorduk. Böylece bize dayatılan tek gazete okuma kuralını yıkmış oluyorduk. (I.Görüşmeci/1979-1990)

Denetim tekniklerinden biri hapishanedeki fiziki koşulların düzenlenmesidir. Örneğin, koğuşlarda ışıklar hiçbir zaman söndürülmemektedir. Mahpusların her an sürekli bir şekilde hapishane görevlileri tarafından görülebilmesi gerekçesiyle söndürülmeyen ışıklar, hapishane yönetimi ve mahpuslar arasında bir çekişme alanı haline gelir:

idarenin belirlediği kurallardan biri de koğuşları dışarıdan görebilmek, kontrol edebilmek için koğuşışıklarının sürekli açık kalmasıydı. Ancak sürekli aynı ışığa maruz kalmak bizim için hiç de iyi değildi, çünkü dinlenmiyorduk ya da psikolojik olarak kötü hissediyorduk. Biz de ampulü gevşetip, ışığı kısarak bizim için daha olumlu olan bir ortam sağlamayı başarabilmiştik. (II. Görüşmeci/1983-1984)

Hapishanelerde gündelik hayat, görüş günlerinin azaltılması ya da tamamen kaldırılması, havalandırma yasağı gibi yöntemlerle, özellikle 1980 askeri darbesinden sonra daha sıkı denetim, disiplin ve gözetime tabi tutulur. Bu duruma karşı siyasi mahkûmlar açlık grevine yönelir. Açlık grevleri sadece günümüzde değil, eskiden beri hapishanelerde mahpusların idarenin baskılarının arttığı dönemlerde kullandıkları bir direniş pratiği olarak değerlendirilmiştir:

1980'lerin ortasında, Sultan Ahmet Cezaevi'ndeydim; oldukça da rahat bir cezaeviydi. Ancak her şey, tek tip elbise uygulaması ile değişti. Süreci ve uygulamayı kabul etmeyenlere de hücre cezaları, havalandırma, görüş, avukat yasakları veriliyordu. Bu süreç aynı zamanda hapishanedeki gündelik hayata ilişkin yeni katı kuralların da getirildiği bir süreçti. Son noktada ise, koğuşlara giren idare görevlileri bize zorla bu giysileri giydirmeye çalıştılar. Bu sürecin sonunda elimizde yapacak başka bir şey kalmadığında tek tip elbise uygulamasını reddetmek için açlık grevine başladık. Idare, bu baskı sürecini kendi yöntemleriyle püskürmeye çalıştı ancak bunda başarılı olamadı, sonunda hepimizi farklı cezaevlerine göndererek Sultan Ahmet Cezaevi'ni büyük oranda boşalttı. (II.Görüşmeci/1983-1984)

1990'ların ikinci yarısından sonra F Tipi hapishanelere geçiş sinyalleri verilir. F Tipini daha önce yurtdışındaki gelişmelerden bilen mahpuslar, esasında tam olarak nasıl bir durumla karşılaşacaklarını tam olarak bilmemektedirler. Ancak, koğuş sisteminin bitmesi onlar için toplumsal ilişkilerinin bitmesi, iletişimsel ve insani boyutta yaşayamamak anlamına gelir. Sürece karşı önce dernekler, sendikalar, çeşitli sivil toplum kuruluşlarıyla kontak kurarak kamuoyunu bilgilendirmek üzere harekete geçerler. Adalet Bakanlığı'ndan belirlenen temsilci ve çeşitli sivil toplum kuruluşları, mahpusların ve siyasi yapıların kendi belirledikleri aydın ve sanatçılardan oluşan bir temsilciler toplamı arasında çeşitli görüşmeler yapııır. Ancak görüşmelerle eş zamanlı olarak basında devlet yetkilileri tarafından F Tipi olarak adlandırılan bu yeni sisteme ne olursa olsun geçecekleri yönünde açıklamalar yapılır. Koğuş sistemi ya da "lineer hapishane sistemi" denilen eski uygulamadan vazgeçilmesinin gerekçelerinden en çok dillendirileni ise "güvenlik" söylemidir. 
Hem mimari olarak hem de içerik olarak koğuş sistemi hapishanelerden tamamen farklı olan bu yeni düzenleme, toplumsal hayatın diğer alanlarından bağımsız değildir. Gündelik hayatın hemen her alanında kayda alınan yüzlerimiz, kişisel bilgilerimiz hatta beğenilerimiz bir bilgi deposu halinde "gözetim toplumu" nun tüm yaşamsal pratiklerini yeniden üretmektedir. İnsanlar, günümüz toplumlarında cadde ve mağazalarda sürekli gördüğümüz "kesintisiz video gözetlemesi uyarıları"nı kanıksayan ve bu durumu sorgulamayan bir şehir hayatı içinde modern iktidarın bilgi nesnelerine dönüşmüşlerdir (Lyon, 2006 ${ }^{18}$, s.101). Bu toplumsal dönüşümün en geçerli nedeni ise hırsızlara, suçlulara ve diğer tehlikelere karşı korunmaktır. Suçlulardan suçsuz insanları korumak, güvenliğini sağlamak ve suçluların da kendi içlerindeki güvenliklerini sağlayarak onlara steril bir hapis hayatı sunmak iktidarın F Tipi sürecine dair öne sürdüğü gerekçedir. Bu gerekçelerle ilgili Yargı Adaleti ve Infaz Planlamacısı olan Melda Türker Yapı Tipolojisi (2003) adlı çalışmasında şöyle söyler:

Türk İnfaz Sistemi İdareciliğinde kurumlarda yatanların devamlı olarak gözetlenip denetlenmesi yoluyla kontrol altında bulundurulmalarının gerekli olduğuna dair idari prensip ve prosedürler gelişmediğinden ötürü, lineer modellerde ısrar edilmektedir. Oysaki lineer modeller batıda, cezaevlerinde güvenliğin ve mahkûmların kontrolünün temin edilmesinde elverişli olmayan ilk kuşak cezaevleri modelleri olarak terkedilmiştir. Dünyanın her ülkesinde olduğu gibi Türk infaz sisteminde de kurum görevlilerinin, mahkûmların birbirinden korunması ve cezaevinde güvenlik ve asayişin temin edilmesi için onların devamlı olarak kontrol altında bulundurulmalarına dair hukuki bir sorumluluk ve yükümlülük altında olmaları gerekmektedir.

F Tiplerinin uygulanmaya konması; 19 Aralık 2000 Hayata Dönüş Operasyonu'ndan sonra gerçekleşir. Tek kişilik ya da üç kişilik hücrelerde yaşayan mahpuslar sıkı bir denetim ve disipline tabi edilmek istenirler. Koridorlardaki kameralar ve sürekli nöbette olan gardiyanlar aracılığıyla da günün her anında kontrol edilirler. Yalnızlaştırmaya ve iletişimden soyutlamaya dayalı bu sistem hapishane mantığının eksiksiz bir şekilde uygulanması sağlamayı hedeflemektedir. Çünkü yalnızlaşan mahkûm, ıslahın olumlu etkisi altına girer; bu durum mahkûmun yalnızlıkla birlikte yaşayacağı pişmanlığı hedeflemektedir. Böylelikle hedeflenen, suçun karşısında yalnız kalan mahkûmun bu yolla suçundan nefret etmeyi de öğrenmesidir (Foucault, 199219, s. 344):

Görüş sonrasında hücreye götürülürken idare görevlileri etrafı görmemem için başımı eğiyorlardı. Koridorların her yerinde kameralar vardı. Aynı anda iki tutuklu ile koridordan geçemiyorduk. Tüm bunları orada kimlerin olduğunu bilmemizi istemediklerinden yapıyorlardı. Diğer mahkûmlarla göz teması kurmamız bile yasaktı. Hücrelerde buna uygun olarak birbirini görmeyecek şekilde yapılandııımıştı. Başlangıçta üç kişilik hücrede kalıyordum ancak hepimizin yeri

18 Kitabın İngilizce orijinal ilk baskısı 2001'dir.

19 Kitabın Fransızca orijinal ilk basımı 1975'tir. 
sürekli olarak değiştiriliyordu. Çünkü hiçbir şekilde sosyalleşmemiz ve iletişim kurmamız istenmiyordu (III.Görüşmeci/1992-2002)

F Tipi hapishanelerde denetim ve disiplin yöntemlerinden biri de gri dışında renklerin, özellikle canlı renklerin yasaklanmasıdır:

\begin{abstract}
Ailelerimiz aracılığıla getirilen giysilere başlarda herhangi bir müdahale yapılmamıştı ancak sonrasında mavi gibi canlı renkler yasaklandı. Gardiyanlar ve bütün görevliler gri ve fulü tonlarda giysiler giyiyorlardı. Bu durum bizi psikolojik olarak olumsuz yönde etkiliyordu. Havalandırmanın köşesinde yemyeşil bir bitki kendiliğinden çıkmıştı. Onu gizli gizli suluyorduk ve idarenin fark etmemesi için de elimizden geleni yapmıştık. Ancak bu yeşil rengin hapishanede barınması uzun sürmedi, kısa bir zaman sonra idare tarafından yok edildi (IV. Görüşmeci/1998-2001)
\end{abstract}

Mahpusların F Tipi hücrelere uyum sağlamaları ve normalleştirilmeleri konusunda psikologlardan yardım alınır. Bu durum panoptikle ilgilidir. Panoptikle birlikte ortaya çıkan durumda artık soruşturma yoktur bunun yerine gözetleme ve incelemeye dayalı teknikler vardır. Bir olayı yeniden ve yeniden soruşturmak yerine bir kimseyi aralıksız olarak ve tümüyle gözetlemek söz konusudur. Bireyler üzerinde bir iktidar uygulayan ve iktidar uyguladıkça hem gözetleme hem de gözetledikleri üzerinde, onlar hakkında bilgi edinebilecek biri; müdür, atölye şefi, psikiyatr, psikolog tarafından bireylerin sürekli gözetimi sağlanır, bu gözetimdeki amaç bireylerin belirlenen kurallara, istenilen yaşam biçimine uyup uymadığını denetlemektir (Foucault, 201120, s.225). Bireyin bilgisine sahip olmak ona dayatılmak istenen her türlü şeyin önkoşuludur. Bu anlamda panoptik iktidar bireyin herhangi bir şeyi neden ve niçin yaptığına dayanan bir soruşturma biçiminden ziyade bireyin bu yeni koşullarla hedeflenen düzeye ulaşması yönündeki tekniklerle ilgilenir. Bu tekniklerden biri psikiyatri alanıyla normallik kaygısı üreterek bireyi hedeflenen düzeye getirmektir:

Hücreler her gün, her hafta düzenli olarak idare ve askerler tarafından kontrol ediliyordu. Haftada bir gün psikologlar hücreye gelerek, ölüm orucuna dair bizimle görüşüyorlardı. Yaptığımız eylemin normal olmadığını ifade ederken bizimle daha çok arkadaşlık ilişkisine benzer bir ilişki kurmaya çalışıyorlardı. Bir taraftan bizi anlamaya çalışıyorlar, ancak öte taraftan da bize bunun doğru bir yöntem olmadığını telkin ediyorlardı. Psikologların yanında ara sıra savcı da bizi ziyarete gelerek onları destekleyen içerikte konuşmalar yapıyordu. (III. Görüşmeci/1992-2002)

\title{
Hapishanelerde mahpusların geliştirdiği haberleşme örnekleri
}

Haberleşme, mahpuslar için hapishaneler var olduğundan beri önemlidir. Gerek birbirleriyle gerek dışarıyla haber alışverişi yapabilmek kimi zaman zorlaşmakta, yasaklanmakta veya kısıtlanmaktadır. Bu nedenle haberleşme, kapatılma mekânı olan hapishanelerde yaratıcı yöntemler gerektirmektedir.

20 Kitabın Fransızca orijinal basımı 1994'tür. 
Haberleşme araçları olarak şekerden, mahpusların kendi imkânlarıyla oluşturdukları teleferik sistemine, seslerle kurdukları haberleşme ağlarına kadar geliştirilen yaratıcı örneklere ulaşılmıştır. 1979'da Mamak cezaevinde kalan görüşmeci, adını cezaevinden alan Mamak Tatlısından bahsetmiştir. Bu tatlı, mahpuslar için eğlenceli zaman geçirmenin aracıyken tatlıyı yapmak için kullanılan şeker bir çekişme nesnesine ve yaratıcı bir yolla inşa edilen iletişim aracına dönüşür:

\begin{abstract}
Mamak tatısı diye bilinen bir tatı var. Mamak Cezaevi'ndeyken sıkça yaptığımız bir tatıydı; peksimet süt ve şeker ile yapılır. Koğuşta şekerimiz bitti, yan koğuştan asker aracılığıyla borç şeker istedik. Asker şekeri getirdiğinde, onu bir kaba dikkatlice boşalttı. Şekeri inceliyordu. Biz de şaşkınlıkla ne yapıyorsun diye sorduk. "Sizin işiniz belli mi olur, şekere de yazı yazarsınız siz" cevabını alınca, daha önce hiç aklımızda olmayan bir yöntemi böylelikle geliştirdik. Birden ona kadar numaralandırdığımız küçük kağıtlara yan koğuştaki arkadaşlarımıza göndermek üzere notlar yazdık. Sonra bu notları katlayıp küçük toplar haline getirdik. Üzerine su da serpiştirince şeker tanelerinin arasında fark edilemeyecek notları diğer koğuşa borcumuz olan şekerle yolladık (I. Görüşmeci/1979-1990).
\end{abstract}

Özellikle 12 Eylül 1980 darbesinden sonra hapishanelerde gözetim ve kontrol mekanizmaları artırılır. 1983'te tüm hapishanelere tek tip kıyafet uygulaması getirilerek mahpusların saç kesimlerinden sakallarına kıyafetlerine ve hapishanenin her yerinde yüksek sesle günün hemen her saatinde çalınan askeri marşlara kadar her şey askeri bir bedene dönüştürülmek istenmektedir. Bu dönemde denetimler sıkılaştırılarak gözetleme teknikleri artırılır. Önceleri koğuşlar arası iletişim yöntemlerinden biri olan mazgallardan bağırarak haberleşme tekniği de bu süreçte işe yaramaz. Sıkı gözetim ve disiplin içinde sürekli asker nöbeti nezaretinde kalan mahpuslar böylece yeni bir sistem kurmak durumda kalırlar. Bu sistem, seslerden oluşan yepyeni bir alfabedir:

Bu süreçte her daim askerin gözetimi altındaydık. Kendi durumumuzu öncelikle koğuş mazgallarından birbirimize bağırarak anlatıyorduk Ancak bizi sürekli gözetleyen askerler de olan biteni duyuyorlardı. Bu durum karşısında biz de sadece bizim anlayabileceğimiz yeni bir alfabe ile anlaşmaya başladık. Rakamların farklı harflere karşılık geldiği bu alfabe21, her bir koğuşun kendi aralarında belirledikleri bir kişi tarafından deşifre edilip kağıda aktarılıyordu. Aynı zamanda her siyasi hareketin kendi alfebesi vardı, sadece onların anlayabileceği şekilde oluşturulan bir alfabe. (II. Görüşmeci/1983-1984)

Ancak sesin yetmediği noktalarda, daha uzak mesafelerde bulunan mahpuslara da haber verebilmek noktasında başka bir yöntem daha geliştirilir. Teleferik sistemi denilen bu yöntem farklı katlarda ve koğuşlarda bulunanlar arasında bilgi alışverişini sağlamaktadır:

21 Özel şifreleme yöntemlerine birçok uygarlıkta rastlanmaktadır. Bu yöntemlerden biri de özellikle Osmanlı, İran, Türk ve Arap kültüründe fizik, matematik, tarih düşme, astronomi mimarlık gibi alanların yanında gündelik ihtiyaçlar ve haberleşmeler için kullanılan harf ve sayı gizemciliği olarak bilinen "ebced hesabı"dır. Görüşmecilerin rakam ve harf denkliğine dayalı olarak kullandığı bu haberleşme yöntemi (farkında olarak ya da olmayarak) aslında kadim bir geleneğin mirasıdır. 
Hapishanede günün dört beş saati hariç idare tarafından sürekli yüksek sesle askeri marşlar çalınıyordu. Dolayısıyla bağırarak iletişim kurmak yetmiyordu. Gerçi bir yerden sonra marşlara rağmen kendi sesimizi duymayı da öğrenmiştik. Birbirimizle iletişim kurmak noktasında geliştirdiğimiz yöntemlerden biri de teleferik sistemiydi. Her koğuşta bulunan bir görevli rakamlardan oluşan alfabeyle iletilmesini istediğimiz notu kağıda aktarıyordu. Ipin ucuna ağırlık yapması için kalemle birlikte not bağlanıyordu. Koğuş kapısının altından diğer koğuşa yollanan bu not alındıktan sonra, yukarıdaki katlarda bulunan arkadaşlarımız da kendilerine yine ip aracılığıla yollanan notu bir kanca aracılığıyla alıyordu. Nota ulaşmak bazen günlerce sürüyordu. Bu sistem esasında biri kalın biri ince olan iki ipten oluşuyordu. Kalın ipin ucuna not bağlanıyordu. Ince olan ip karşı taraftan çekildiğinde kalın ipe bağı not kendilerine doğru geliyordu. Aslında kendi aramızda bir ağ örmüş oluyorduk. Idarenin fark etmemesi için teleferik sistemi her daim üst katta bulunurdu (II. Görüşmeci/1983-1984)

Çok eski bir haberleşme aracı olan güvercinler hapishanedeki mahpuslar için de iletişim açısından önemlidir. Koğuşların demirli pencerelerine konan güvercinler yakalanıp, ayaklarına birtakım bilgilerin olduğu notlar bağlanır. İdare tarafından fark edilen bu durumdan sonra güvercinler silah sesiyle ya da başkaca yöntemlerle hapishane çevresinden uzaklaştırılır:

Koğuş pencerelerine konan güvercinleri, bir ayağına tutturulan not ve diğer ayağına bağlanan ip ile haberleşme için kullanıyorduk. Ipin bir ucunu elimizdeydi, sonra da güvercini pencereden uzaklaştırıyorduk. ip elimizde olduğundan, bu genelde kısa bir ip oluyordu, güvercinin gideceği mesafeyi ve pencereyi de belirliyorduk. Ancak bu durumu fark eden idare bir süre sonra penceresine güvercin konan koğuşlarda arama başlatıp, güvercinleri hapishaneden ürküterek uzaklaştırdı. (II. Görüşmeci/1983-1984)

Hapishanede her koğuşun ayrı bir havalandırması bulunmaktadır. Mahpuslar farklı koğuşlarda olan arkadaşlarına haber yollamak için kağıt, gazete ya da ağırlık yaratacak herhangi bir maddeden toplar yaparak içlerine iletmek istedikleri notu yerleştirirler:

Diğer hapishanelerde de kullanılan ve siyasi mahkûmlar için çok eski bir yöntem olan haberleşme topları her daim bizim için önemli bir araçtı. Kağıda yazdığımız notu, ağırlık oluşturarak top haline getiriyorduk. Topun üzerine notun ulaşması gereken kişinin ismi yazıyorduk. Buradan önemli olan bizim için notun muhatabına ulaşana kadar okunmadan havalandırmalar arasında gitmesiydi. Topun üzerinde notun ulaşması gereken kişinin bulunduğu bloğu ve ismi yazıyorduk, örneğin, Mehmet Ali, C-Blok şeklinde bir bilgi yazılıyordu. Böylece aynı koğuşta olamasak da birbirimizle haberleşmiş oluyorduk (III. Görüşmeci/1992-2002)

1990'ların sonunda Türkiye'de genel olarak hapishanelerdeki gözetim ve denetim artmıştır. Keza, 2000'de F Tipi hapishanelerin varlığı da denetimin ve güvenliğin sağlanamadığı gerekçesiyle gündeme gelmiştir. 1990'ların sonunda hapishane pratiğini yaşamış mahpuslarla yapılan görüşmelerde, gündelik hayatlarının aşama aşama hızlı bir şekilde sekteye uğradığı sonucu çıkmaktadır: 
Mektup, görüş, avukat, revir gibi haklar kısıtlanmaya başlamıştı. Eskiden görüşe gelenlerin tutuklularla soyadı zorunluluğu yokken, soyadı zorunluluğu bir kural olarak ișletilmeye bașlandı. Koğușların kontrolü ve bu kontrolle birlikte üzerimizdeki baskı da arttı. Tüm bunları idare ile yazışmalarımızda ifade ettik. Kazanılmış haklarımızın gasp edildiğini ifade ederek durumu anlatmak ve bu durumun bir son bulması için yetkili kurum ve kişilerle diyalog yöntemini kullandık. Ancak buradan bir sonuç alınamadığımız gibi baskılarda da artış oldu. (IV. Görüşmeci/1998-2001)

Bauman'ın ifade ettiği haliyle mekânın inşasında önemli olan mekânın üzerinde toplumsal ilişki ve bağlılıklar üzerinde yasal, siyasi ve idari hâkimiyet sağlamaktır. Mekânın üzerindeki asıl savaş da "harita bürosuna hâkim olma savaşı"dır. Bu mekân savaşındaki hedef, mekânın kodlarının hükümet ve devlet memurları tarafından mükemmel bir biçimde okunabilmesi, ancak kullanıcı ve kurbanlarının yorumlarına tamamen kapalı olmasıdır. Bu anlamıyla modern devlet için mekân üzerinde tek bir harita olması amaçlanmaktadır. Modern mekân savaşı; mekânın parçalarını, yukarının bilemeyeceği, anlaşılmaz anlamlarla dolduran, parçaları kontrol edilemez hale getiren tabanın tüm yorumlama girişimlerine direnen bir algıya sahiptir (Bauman, 201422:s.40).

Foucault, Hapishane'nin Doğuşu'nda (1975) şöyle söyler: "Pennsylvania hapishanesindeki yegane ıslah işlemleri vicdan ve bunun çarptığı dilsiz mimaridir. Chery Hill'de duvarlar suçun cezasıdır; hücre tutukluyu kendi mevcudiyetinin karşısına koyar".

Koğuş sistemi denetlenemediği gerekçesiyle mahpusların kendilerinden başka bir tek soluk gri renk üniformalı gardiyanı görebildikleri, tek kişilik ya da üç kişilik hücrelerden oluşan F Tiplerine dönüştürülür. Buradaki amaç, Foucault'nun sözünü ettiği anlamıyla hücrenin tutukluyu kendi mevcudiyetinin karşısına koymasıdır.

F tiplerinde renklerden sese her şey sıkı bir gözetim ve denetim altındadır. Gardiyanların kıyafeti bile gridir. Başka bir renk yoktur. Ancak tek kişilik ya da üç kişilik hücrelere kapatılan mahpuslar her ne kadar bir yalnızlaştırma ve iletişimsel olarak soyutlama politikasına tabi kılınmak istenseler de bu duruma karşı farklı yöntemler ararlar:

Hücrelerde kimlerin kaldığına dair bir bilgimiz yoktu. Bu durum idare tarafından özellikle saklanıyordu. Biz de diğer hücrelerde kimlerin kaldığını öğrenmek için kağıdı top yaparak havalandırmalara atıyorduk. Top, üzerindeki yazılı isme ulaşana kadar havalandırmaların arasında dolaşıyordu. Böylece, hangi hücrede kimin kaldığını öğrenebiliyorduk. Böylelikle yalnız olmadığımızı, dostlarımızın da yakınlarımızda olduğunu bilerek daha iyi hissediyorduk. (IV. Görüşmeci/1998-2001)

22 Kitabın İngilizce orijinal basımı 1998' dir. 
Son olarak iletişim, bilincin ötekine kendisi aracılığıyla yönelmesinin sonucudur. Bu anlamda iletişim, bilincin hem içinde bulunduğu çevreye hem de başka insanlara yönelmesi bağlamında kendi varlığına yeryüzünde bir yer açmasıdır (Dursun, 2013, s.21) Eski bir haberleşme ve iletişim aracı olan mektupla yaşanan heyecan hayatta kalabilmek için umut taşır:

\begin{abstract}
Mektup yazmak hem yakınlarımla iletişim kurmamı hem her anlamda hem kendimi ifade edebilmemi hem de umutlu olabilmemi sağlıyordu. Aileme ya da sevdiğim insana yazdığım mektuplar geçmişimi ve kim olduğumu bana yeniden anımsatıyordu. Çok özel bilgilerin olmadığı bu mektuplarda, kişisel duygularım dışında sevdiklerimle aynı yerde aynı anda olabilmenin heyecanını yaşıyordum. Bu şöyle oluyordu; mektubun alıcıya ulaşma süresini hesap edip, farklı yerlerde olsak da aynı tarihte aynı saatte belirlediğimiz bir yıldıza bakarak bir sigara içebiliyor ya da aynı şarkıyı söyleyebiliyorduk (IV.Görüşmeci/1998-2001)
\end{abstract}

Bu görüşmeler, hem hapishane pratiğinin Türkiye'deki dönüşümünü hem de hangi koşulda olursa olsun iktidarın bir önkoşulu olarak direniş alanları yaratabilmenin mümkün olduğunu göstermektedir. Bu durum, çalışmanın ana izleği olan iktidarın kendi doğasıyla, onun işlemek istediği kişiler üzerinde bıraktığı boşluklarla ilişkilidir. Çünkü iktidar süreğen sayısız çatışmalar üzerinden ve bu çatışmaları bastırmak, önünü almak ya da tedavi edebilmek adına geliştirdiği bilgi alanları yaratır.

Bu anlamda iletişim de insani bir deneyim olarak iktidarın çekişme alanı içinde bir karşı duruş ve direniş alanı olarak ortaya çıkar.

\title{
Sonuç
}

Iktidar teoriden çok pratik uygulama alanlarıyla işler. Bu anlamda iktidarın ne dediğinden çok ne yaptığı önemlidir. Hapishanelerdeki dönüşüme dair iktidar kanalıyla üretilen söylemsel düzlemin aslında ne olduğu, neye yol açtığı pratikte yani bizzat gündelik hayatta vuku bulmaktadır. Dolayısıyla hapishanelerde koğuş tiplerinden F Tipine geçişte, gündelik hayata ilişkin pratiklere içeriden bakmak bir iktidarı analizi yapmak demektir.

Çalışmada Foucault'nun iktidar analizleri doğrultusunda modern devletin oluşumundaki temel paradigmalara değinilmiştir. Bireyi kontrol ederek, bireyin bilgisine sahip olarak ona yeni özneleşme süreçleri dayatan modern devlet iktidarı bu özneleşme süreçleri ile bir tabi olma ilişkisi yaratmaktadır. İktidar, bu anlamıyla birey ve toplum üzerinde sonsuz dönüşümler kurmayı hedefler. Varlığı bu dönüşümlerle mümkündür. Sürekli yeni teknikler geliştiren modern iktidar için mekân kontrol ve denetimin açıkça yapılabildiği bir uygulama alanına dönüşür. Dolayısıyla mekân üzerinde de sürekli bir dönüşüm söz konusudur.

Çalışmada Foucault'nun iktidarın bir önkoşulu olarak değerlendirdiği özgürlük ve özgür özne kavramlarının hapishanelerde nasıl var olduğu sorusuna 
yanıt aranmıştır. Yapılan görüşmelerde iktidarın uygulama alanlarından biri olan hapishane mekânı üzerindeki temel kontrol noktası olan iletişim ve gündelik hayat üzerindeki çekişmenin temel bir mücadele alanı olduğu görülmüştür.

İnsanı insan yapan en temel pratiklerden belki de en önemlisi iletişim kurabilmektir. Toplumsal bir varlık olan insan, diğeriyle gerçekleştirdiği paylaşım pratikleriyle insan olarak kalabilmektedir. Simgesel paylaşım alanları, ortak duygular, oyunlar, düşünceyi ifade etme yolları hapishane mekânında da insan kalabilmek için önemli pratiklerdir. Çalışmada bu anlamda dayatılan tekniklerin tüm profesyonelliğine rağmen mahpusların kendilerini var edebilmek için yaratıcı yollar inşa edebildikleri görülmüştür. Bu günümüzde en profesyonel araçların kullanıldığı F Tipleri için de geçerlidir. Iktidar F Tipleri ile gözetlemenin ve disipline edici aygıtların yaratılmasında tüm teknik gelişmeleri kullanmıştır. Ancak giysilerden renklere kadar katı bir tahakkümün uygulandığı $F$ Tiplerinde de mekân üzerinde bir çekişme olduğunu görmekteyiz. Bu çekişme alanları 1980'lerde toplu yaşama imkânına sahip mahpusların ekmek içinden yaptığı satranç taşlarından yalnızlık, renksizlik ve sessizlikle inşa edilen F Tipi hapishane mekânında görüşmecilerden birinin ifade ettiği haliyle yeşil bir bitkinin, "Havalandırmanın köşesinde yemyeşil bir bitki kendiliğinden çıkmıştı. Onu gizli gizli suluyorduk ve idarenin fark etmemesi için de elimizden geleni yapmıştık", muhafazasına kadar devam etmektedir.

Teorik anlamda Foucault'nun modern devlet ve iktidara ilişkin analizleriyle ilgili literatürde sayısız çalışma bulunmaktadır. Ancak bu çalışma yapııırken hapishanelere dair özellikle özgürlük, direniş ve özneler üzerinden pratik anlamda bir alan çalışmasının olmadığı görülmüştür. Bu çalışmanın gayesi de literatürdeki bu boşluğa ilişkin en azından küçük bir kapı açabilmektir. Böylelikle tarihin bir kesitine ve mekânın belli anlarına sadece yukarıdan bir bakışla; yapanlar, dayatanlar, yasa koyanlar tarafından değil, aşağıdan yani belli iktidar tekniklerine maruz kalanların yaratıcı yollarıyla inşa edilen mücadele pratiklerinden bakabilmek mümkün olmuştur.

\section{Kaynakça}

Bauman, Z. (2012). Yasa Koyucular ile Yorumcular. (K. Atakay, Çev.). Üçüncü Baskı, İstanbul: Metis Yayınları.

Bauman, Z. (2014). Küreselleşme. (A. Yılmaz, Çev.). Beşinci Baskı, İstanbul: Ayrıntı Yayınları.

Dursun, Ç. (2013). İletişim Kuram Kritik. Birinci Baskı, Ankara: İmge Kitabevi.

Foucault, M. (1992). Hapishanenin Doğuşu. (M. A. Kılıçbay Çev.).Beşinci baskı, Ankara: Imge Kitabevi Yayınları.

Foucault, M. (2011). Bilginin Arkeolojisi. (V. Urhan Çev.). Birinci Baskı, İstanbul: Ayrıntı Yayınları. 
Foucault, M. (2011). Büyük Kapatılma. (I. Ergüden, F.Keskin Çev.). Üçüncü Baskı, İstanbul: Ayrıntı Yayınları.

Foucault, M. (2011). Entelektüelin Siyasi İşlevi. (I. Ergüden, vd.,Çev.). Üçüncü Baskı, İstanbul: Ayrıntı Yayınları.

Foucault, M. (2011). Özne ve Iktidar. (I. Ergüden ve O. Akınhay Çev.).Üçüncü Baskı, İstanbul: Ayrıntı Yayınları.

Foucault, M. (2012). Iktidarın Gözü, (I. Ergüden Çev.).Üçüncü Baskı, İstanbul: Ayrıntı Yayınları

Foucault M. (2013). Toplumu Savunmak Gerekir. (Ş.Aktaş Çev.). Altıncı Baskı, Ankara: YKY Yayınları.

Harvey, D. (2014). Sosyal Adalet ve Şehir. (M.Moralı Çev.). Dördüncü Baskı, İstanbul: Metis Yayınları.

Keskin, F. (2011). Özne ve İktidar, M. Foucault, Özne ve İktidar: Seçme Yazılar 2 İçinde (11-25). Ankara: Ayrıntı Yayınları.

Lefebvre, H. (2013). Gündelik Hayatın Eleştirisi (2). (I. Ergüden Çev.). Birinci Baskı, İstanbul: Sel Yayınları.

Lyon, D. (2006). Gündelik Hayatı Kontrol Etmek" Gözetlenen Toplum.(G. Soykan Çev.). İstanbul: Kalkedon Yayınları.

Öztürk, S. (2012). Mekân ve İktidar, Birinci Basım, Ankara: Phoneix

Revel, J. (2005). Güncelliğin Bir Ontolojisi, (K. Atakay Çev.) Birinci basım, İstanbul: Otonom Yayıncilık

Türker M. (2003). Yapı Tipolojisi, "F Tipi" Cezaevi Mimari Tasarımının Çağdaş Cezaevleri Mimari Modellerinin Gelişme Sürecindeki Yeri, Ege Mimarlık Dergisi, 2 (46), 43-45. 
